\title{
KULTURA LUDOWA JAKO WSPÓLNY PRZEDMIOT ZAINTERESOWAŃ POLSKICH I UKRAIŃSKICH TWÓRCÓW ORAZ BADACZY WE LWOWIE NA PRZEŁOMIE XIX I XX WIEKU
}

\author{
Vira Neszew \\ Uniwersytet Kardynała Stefana Wyszyńskiego \\ Warszawa, Polska \\ ORCID: 0000-0001-6776-6914
}

\section{FOLK CULTURE AS A SPACE FOR POLISH-UKRAINIAN DISCUSSIONS IN LVIV AT THE TURN OF THE 19TH AND 20TH CENTURIES}

\begin{abstract}
The essay is an attempt to reconstruct Polish-Ukrainian discussions about literature and science in Lviv through the prism of folk culture. On the one hand, the fascination with the populace united Polish and Ukrainian intellectuals, and on the other, it was often a reason for discussions within these circles. Critical-literary texts on folk issues, published in the selected Lviv press at the turn of the 19th and 20th centuries, are a testimony to the active intellectual cooperation of Poles and Ukrainians, as well as mutual interest in the development of the neighbor's culture.
\end{abstract}

Key words: Polish-Ukrainian literary contacts, Polish-Ukrainian scientific contacts, folk culture, polemics, modernism, Young Poland, "Young Ukraine", Lviv, the turn of the 19th and 20th centuries

Na progu XX wieku w polskiej i ukraińskiej literaturze modernistycznej obserwuje się fascynację kulturą ludową, wynikającą z powszechnie odczuwanego kryzysu cywilizacyjnego. W tym czasie folklor był żywym, bijącym źródłem, które mogło przyczynić się do odnowienia literatury poddającej się cywilizacyjnemu znużeniu ${ }^{1}$. Na przełomie wieków ludowość stała się również przedmiotem badań naukowych, czego efektem są prace polskich i ukraińskich etnografów.

$1 \quad$ Zob.: E. Lesisz, Huculszczyzna - w kręgu mitów polskich na przełomie XIX i XX wieku, Warszawa 2013; J. A. Choroszy, Huculszczyna w literaturze polskiej, Wrocław 1991; L. Tatarowski, Ludowość w literaturze Młodej Polski, Wrocław 1991; С. Павличко, Дискурс модернізму в українській літературі, Київ 1997; Т. Гундорова, ПроЯвлення Слова. Дискусія раннього українського модернізму, Київ 2009. 
Polskich i ukraińskich intelektualistów łączyła nie tylko fascynacja folklorem, lecz również instytucje kultury i nauki, w których spotykali się na co dzień. Iwan Franko, Stanisław Zdziarski, Włodzimierz hr. Dzieduszycki, Adam Fischer, Wołodymyr Szuchewycz, Wołodymyr Hnatiuk należeli do polskiego Towarzystwa Ludoznawczego ${ }^{2}$. W tym czasie ważnym miejscem spotkań ukraińskich naukowców było Towarzystwo Naukowe im. Tarasa Szewczenki, na którego posiedzeniach były omawiane nowości badawcze i teoretyczne, co znajdowało odzwierciedlenie w ,Zapyskach Naukowego Towarzystwa im. Tarasa Szewczenki" (organie wydawniczym NTSz ${ }^{3}$ ), gdzie po raz pierwszy została opublikowana praca Ołeksandra Kolessy pt. Украӥнські народні nісні в поезіях Богдана Залеського ${ }^{4}$ [Ukraińskie pieśni ludowe w poezjach Bohdana Zaleskiego], której wersja polskojęzyczna powstała dopiero osiem

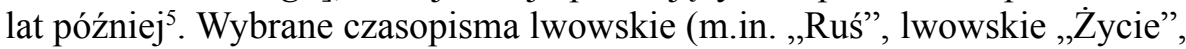
„Tydzien" (dodatek „Kuriera Lwowskiego”) otwierały swoje łamy dla prezentowania stanowisk oraz dyskusji polskich i ukraińskich intelektualistów, ułatwiały wymianę poglądów pomiędzy przedstawicielami tych środowisk. $\mathrm{Na}$ łamach czasopisma „Lud” (organu wydawniczego Towarzystwa Etnograficznego) ukazywały się recenzje prac Oleksandra Kolessy o tematyce ludowej, których autorem był Stanisław Zdziarski. Ten ostatni natomiast w roku 1898 w ,Zapiskach Naukowego Towarzystwa im. Tarasa Szewczenki” w dziale Miscellanea opublikował tekst poświęcony wybitnemu etnografowi, badaczowi słowiańskiej kultury ludowej, Żegocie Paulemu ${ }^{6}$. W „Literaturno-naukowym Wistnyku" ukazał się tekst Iwana Franki, szczegółowo omawiający spór, jaki Szuchewycz toczył z członkami Naukowego Towarzystwa im. Szewczenki, dotyczący Huculszczyny ${ }^{7}$.

Zainteresowanie ludowością stało się jedną z ważnych cech postawy młodopolan, przeciwstawiających się literaturze, która „chyliła się ku upadkowi”. Na przykład wspomniany już Zdziarski dowodził, że inspiracja kulturą ludową prowadzi do ożywienia sztuki dzięki sięganiu po oryginalne formy, obrazy,

\footnotetext{
2 Informacje o zarządzie Towarzystwa oraz 64 członkach zostały zamieszczone [w:] Sprawozdanie z pierwszego Walnego Zgromadzenia, „Lud. Organ Towarzystwa Ludoznawczego we Lwowie" 1895, s. 29-30. Wiadomości o zwiększającym się składzie Towarzystwa podawano w każdym roczniku „Ludu” w rubryce pt. Spis wspótpracowników.

W tekście używam skrótu NTSz [Naukowe Towarzystwo Tarasa Szewczenki].

4 О. Колесса, Українські народні пісні в поезіях Богдана Залеського, „Записки наукового товариства ім. Шевченка" 1892, cz. I, s. 124-208.

A. Kolessa, Ukraińska rytmika ludowa w poezyach Bohdana Zaleskiego, Lwów 1900.

6 С. Здзярский, 3 паперів Жетоти Паулі, „Записки Наукового Товариства ім. Шевченка” 1898 , s. $1-6$.

7 I. Франко, Дещуо про нащу пресу, “Літературно-науковий вістник” 1905, t. 8, ks. 8, s. $174-188$.

8 Zakończenie, [w:] S. Zdziarski, Pierwiastek ludowy w poezji polskiej XIX wieku. Studia porównawczo-literackie, Warszawa 1901, s. 574.
} 
nastroje. Ten badacz twórczości polskich romantyków podkreślał fakt silnego oddziaływania kultury ludowej na ich dzieła. Wskazywał wpływ folkloru,

któremu ulegli niemal wszyscy wybitniejsi poeci [...] XIX stulecia aż do chwili ostatniej, w której ów wpływ wzrasta, czego dowodem są piosenki Konopnickiej, wioskowe mazurskie postacie Kasprowicza, lub wreszcie z krainy baśni zaczerpnięte widziadła w Zaczarowanym kole Rydla9.

Autor przekonywał, że dla pisarzy polskich nie tyle literatura, co kultura ukraińska stawała się źródłem inspiracji. Wskazywał wartości, które przyciągały ówczesnych polskich twórców do tej kultury, pisząc o jej otwartości i szczerości: „Znam lud inny, osiadły wśród bujnych stepów Ukrainy i Podola, mniej od polskiego zamknięty w sobie, a za to do głębi duszy i serca przesiąkły melancholijnym smutkiem" ". Już na wstępie omawianej pracy autor akcentował fakt, że to właśnie obcowanie z kulturą ukraińską, jej śpiewnym językiem kształtowało fascynacje folklorystyczne, a przez to wyznaczyło kierunek zainteresowań naukowych polskich badaczy kultury ludowej:

[...] chciałbym pracą niniejszą [...] spłacić dług, jaki w latach pacholęcych zaciągnąłem wobec ruskiej dumy ludowej, którą karmiło się serce i uczucie nie przez jedną chwilę, wobec opowieści chłopskich, których tylu nasłuchałem się w ciemne zimowe wieczory przy blasku łuczywa - w podolskim dworku szlacheckim. Za chwile te błogie, za te melodie, jękiem przeciągłym rozpłakane, za te kazki, tęczową lśniące barwą - skąpa to będzie zapłata, ale zapłata, złożona szczerym sercem $^{11}$.

Przełom XIX i XX wieku nie jest okresem, w którym po raz pierwszy obserwuje się zainteresowanie kulturą ludową, ujawniające się w literaturze czy sztuce. Fascynacja ludowością była elementem rozpoznawalnym „ukraińskiej szkoły" polskich romantyków, której przedstawiciele zwracali szczególną uwagę na ukraińską kulturę ludową, przenosząc ją w oryginalny sposób do literatury pięknej.

Iwan Franko w 1885 r. w artykule Adam Mickiewicz w rusińskiej literaturze, poświęconym problemom obecności nurtu ludowego w polskiej literaturze romantycznej, zwracał uwagę na to, że fascynacje literackie Polaków wydatnie wpływały na zainteresowanie folklorem w rusińskich środowiskach intelektualnych w Galicji:

$9 \quad$ Przedmowa, [w:] S. Zdziarski, Pierwiastek ludowy ... dz. cyt., s. VI.

10 Władystaw Orkan, [w:] S. Zdziarski, Pierwiastek ludowy ... dz. cyt., s. 570.

11 Przedmowa, [w:] S. Zdziarski, Pierwiastek ludowy ... dz. cyt., s. VI-VII. 
[...] pod wpływem tego elementu ludowego ukraińskiego, pod wpływem ludowej poezji i ukraińskich tradycji historycznych wyrasta wspaniały kwiat poezji romantycznej, wyrasta tzw. ukraińska szkoła poetów polskich. Szkoła ta, wnosząc niejako całe nowe światy ducha i formy w poezję polską, równocześnie musiała oddziaływać i na przebudzenie narodowe Rusinów, stawiając im żywym przykładem przed oczy tę konsekwencję, że jeżeli rusińska duma lub powieść ludowa w obcą, polską szatę przybrana, mogła wywierać tak potężny, czarodziejski wpływ, to czyż nie może ona wywrzeć takiego samego wpływu w swej własnej rodzimej formie, w języku ruskim. Zresztą i innym, więcej bezpośrednim sposobem wpłynęli Polacy na odrodzenie narodowej literatury rusińskiej: rozumiem tutaj zebranie i publikowanie pieśni ludowych, rozpoczęte przez Zoryana Dołęgę Chodakowskiego (A. Czarnockiego), a później prowadzone przez Wacława z Oleska (Zaleskiego) i Żegotę Paulego z Galicji ${ }^{12}$.

Sformułowany przez Frankę problem znalazł swoje odzwierciedlenie również w pracy Kolessy pt. Ukraińska rytmika ludowa w poezyach Bohdana Zaleskiego. Ukraiński uczony przedstawiał twórczość poety piszącego w duchu ukraińskiej szkoły polskiego romantyzmu:

Charakter poezji Bohdana Zaleskiego, a także cały kierunek jego twórczości jest bardzo związany z ogólnym powrotem do poezji ludowej w ówczesnych literaturach europejskich, a przede wszystkim z romantycznymi kierunkami, które obserwujemy od początku tego wieku w literaturze polskiej i ukraińskiej $[\ldots]^{13}$.

Praca Kolessy została przy tym odnotowana w polskich środowiskach intelektualnych jako jedno z najbardziej dociekliwych studiów dotyczących związków Zaleskiego z kulturą ludową. Pisał o niej Zdziarski:

Studia nad stosunkiem naszej poezji artystycznej do twórczości ludowej leżały dotąd niemal zupełnie odłogiem. Albowiem oprócz kilku drobnych notatek jedynie prace Dra Aleksandra Kolessy o Bohdanie Zaleskim rzuciły na tę kwestię spory snop światła ${ }^{14}$.

Polski krytyk skupił się w recenzji na omówieniu zagadnienia „melodyjności” poezji Zaleskiego, którą Kolessa usiłował gruntownie zbadać:

12 I. Franko, Adam Mickiewicz w rusińskiej literaturze, „Kraj” 1885, nr 46, s. 28.

13 О. Колесса, Українські народні пісні в поезіях Богдана Залеського, „Записки наукового товариства ім. Шевченка” 1892, cz. I, s. 124. Tekst oryginału: „Характер поезій Богдана Залєского та цілий напрям єго творчества тісно зв'язаний з загальним наворотом до поезії людової в європейських тогочасних літературах, а передовсім з романтичними прямуваннями, які бачимо з початком сього століття в літературі польській та українській [...]”. Wszystkie cytaty w języku ukraińskim podaję w tłumaczeniu własnym.

$14 \quad$ S. Zdziarski, Pierwiastek ludowy ... dz. cyt., s. V. 
Nikt atoli nie zadał sobie trudu, ażeby wyświetlić powód melodyjności i zbadać go dokładnie a wszechstronnie. Zadania tego żmudnego podjął się szan[owny] autor, ile zaś ono pracy i czasu kosztowało, zrozumie każdy, kto przeglądnie systematykę wzorów rytmicznych znajdujących się w poezjach Zaleskiego [... $]^{15}$.

Warto przy tym zasygnalizować, że publikacja Kolessy nie była odosobniona, wpisywała się ona w szerszy nurt rozważań na temat ludowych odniesień w twórczości polskiego romantyka. Na przełomie XIX i XX w. ukazały się bowiem obszerne prace, szczegółowo analizujące twórczość tego poety, a wśród ich autorów znalazł się - oprócz Zdziarskiego ${ }^{16}$ - także Józef Tretiak $^{17}$. Zdziarski uzasadniał intencje swojej pracy:

[...] niechaj [praca] będzie świadectwem, że ci, co wzrośli na ruskiej ziemi i z niej brali pokarm w latach zarannych, mają w pamięci imiona bożych śpiewaków, swoich współplemiennych, - a zarazem niech stanie się fundamentem, na którym ktoś wyrzeźbi w przyszłości i lepsze, i wszechstronniej pojęte, i więcej do rzeczywistego podobne oblicze duchowe poety ${ }^{18}$.

Pisząc o polskim romantyku wydobywał oryginalność jego twórczości, polegającą na melodyjności poezji porównywanej do pieśni ukraińskich kobziarzy, śpiewających o trudnej historii swojego narodu:

[...] Zaleski był i jest dotąd najlepszym lirykiem doby romantyzmu polskiego, zobaczymy, że przechował się on w swojej poezji jako typ osobny, jako typ ukraińskiego siwobrodego gęślarza, co z dalekiej obcej ziemi jęczał pieśnią tęsknoty pełną za ukochaną stroną ${ }^{19}$.

Według Franki publikacja Zdziarskiego nie przyczyniła się jednak do pogłębionej analizy polsko-ukraińskich relacji kulturowych, gdyż jej autor skupiał się bardziej na biografii Zaleskiego, niż na jego literackich dokonaniach:

15 A. Kolessa, Ukraińska rytmika ludowa w poezjach Bohdana Zaleskiego (St. Zdziarski), „Lud. Organ Towarzystwa Ludoznawczego we Lwowie” 1901, r. 7, s. 227.

16 S. Zdziarski, Bohdan Zaleski. Studium biograficzno-literackie, Lwów 1904.

17 Józef Tretiak (1841-1923) - krytyk literacki, historyk literatury. W latach 1867-1868 mieszkał i pracował we Lwowie (recenzent literacki i teatralny w „Gazecie Narodowej”, nauczyciel języka polskiego w II Gimnazjum), był członkiem Towarzystwa Literackiego we Lwowie. W późniejszych latach przeniósł swoją działalność naukową (był profesorem Uniwersytetu Jagiellońskiego) i wydawniczą do Krakowa. Głównym obszarem zainteresowań Tretiaka była literatura romantyczna (między innymi twórczość Mickiewicza oraz Słowackiego), badał wpływy Mickiewicza na twórczość Szewczenki. Źródło: Tretiak Józef, [w:] Literatura polska. Przewodnik encyklopedyczny, red. J. Krzyżanowski, C. Hernas, A. Hutnikiewicz, t. 2, Warszawa 1985, s. 496-497.

18 S. Zdziarski, Bohdan Zaleski. Studium biograficzno-literackie, Lwów 1904, s. VII.

19 Tamże, s. 419-420. 
Dla historyka literatury ukraińskiej, a nawet dla ukraińsko-polskiej społeczności praca ta jest mało interesująca. Jej pierwszy rozdział, gdzie została opisana młodość i lata szkolne Zaleskiego spędzone na Ukrainie, i rozdział IV, w którym opowiada się o jego krótkim pobycie w Galicji po upadku powstania 1831 r., to wszystko, czym zachwyca polski poeta nasz kraj. Późniejsze lata życia i emigracji dają nieco okazji do pokazania słowiańskich i ukraińskich sympatii i antypatii Zaleskiego [...] jednak na te okazjonalne momenty dr Zdziarski za mało zwraca uwagi, a może za mało znalazł materiałów do ich pełnego naświetlenia ${ }^{20}$.

Intencja zbadania przez polskich (Zdziarski, Tretiak) i ukraińskich (Franko, Kolessa) intelektualistów lwowskich tak zasadniczego problemu twórczości literackiej wybranych polskich romantyków (m.in. Mickiewicza, Zaleskiego), jak obecność w niej wątków i motywów ludowych, świadczyła o chęci prześledzenia nieustannych inspiracji folklorem w literaturze polskiej nie tylko ostatniej doby, lecz powstającej na przestrzeni ostatnich stu lat (od romantyzmu aż do modernizmu w polskiej i ukraińskiej odmianie).

\section{MŁODOPOLSKIE FASCYNACJE LUDOWOŚCIĄ}

Wypowiedzi polskich i ukraińskich pisarzy i krytyków literackich, ukazujące się pod koniec XIX i w pierwszym dziesięcioleciu XX wieku świadczyły o nasileniu wpływów kultury ludowej na ówczesnych twórców. Literatura, w której folklor stał się istotnym elementem, przyciągała i zyskiwała coraz więcej odbiorców. Dorobek literacki Jana Kasprowicza, Kazimierza Przerwy-Tetmajera, Władysława Orkana, Wasyla Stefanyka oraz innych polskich i ukraińskich pisarzy ukazuje sposoby czerpania z folkloru, a obecna w ich twórczości ludowość stawała się elementem scalającym kulturę polską i ukraińską na przełomie XIX i XX w., uświadamiała też szerszej społeczności, że egzystencja chłopa-Polaka i chłopa-Rusina ma więcej podobieństw niż różnic.

Ukraińskich twórców w szczególny sposób interesował dorobek literacki Kasprowicza, któremu udało się połączyć polską ludowość z wysoką kulturą estetyczną: „Syn wieśniaka z pruskich Kujaw, uczeń szkół niemieckich, przy-

\footnotetext{
20 [b. а.], Бібліографія (Іван Франко, Stanisław Zdziarski - Bohdan Zaleski, studium biograficzno-literackie), „Записки Наукового товариства ім. Шевченка” 1902, t. 47, ks. 3, s. 32-33. Tekst oryginału: „Для історика української, навіть українсько-польської суспільности ся праця дає мало інтересного. Перший їі розділ, де описана молодість та шкільні літа Залєского прожиті на Україні, і розд. IV, де оповідається про його короткий побут у Галичині по упадку повстання 1831 р., ось і все, чим захоплює польський поет нашу країну. Пізніші часи життя на еміграції дають дещо до показання словянських і українських симпатій та антипатій Залєского [...], але на ті принагідні моменти д. Здзярский за мало звертає уваги, й може й за мало знайшов матеріялів для їх повного освітлення”.
} 
niósł ze sobą dwie rzeczy, których nie miała większość polskich poetów: dokładną znajomość życia wiejskiego i szeroką literacką oświatę, a także znajomość klasycznych i współczesnych literatur"21. Kasprowicz fascynował ludzi kultury, gdyż był im bardzo bliski mentalnie, miał naturalną umiejętność opisywania skomplikowanych realiów życia ubogich mieszkańców wsi, co ukraińskim pisarzom pozwalało orientować się $\mathrm{w}$ aktualnych problemach polskiego społeczeństwa, sięgać do istoty chłopskiej egzystencji. Franko pisał o nim:

[...] to instynktowne uczucie, ten dreszcz tajemniczy, jaki czasem przebiega rozhisteryzowane, wychuchane lalki salonowe, gdy w ich towarzystwo ni stąd ni zowąd pojawi się - chłop, prosty chłop, w siermiędze, w ciężkich butach, z grubymi rękami, od których czuć odór karmiącej go ziemi.

Takim gościem z innego świata jawi się Kasprowicz w poezji polskiej. Ten odmienny duch, obecny w jego wierszach, odczuwają krytycy postępowi ${ }^{22}$.

Franko, pisząc o elementach ludowości obecnych w twórczości Kasprowicza, cenił go za literackie wyrobienie i styl artystyczny. Uważał, że pozycja poety była wyjątkowa, gdyż: ,[...] prawdziwa pieśń ludowa w polskiej, jak i w każdej innej literaturze zabrzmieć może tylko spod wieśniaczej strzechy." ${ }^{23}$. Te „dźwięki twardsze, chropowate, dochodzące nieraz do formalnego zgrzytu"24, które wprowadził do poezji polskiej Kasprowicz, wyznaczały - według Franki - nowy kierunek jej rozwoju, który w ostatnich dziesięcioleciach XIX w. zdobywał coraz więcej zwolenników.

Już na początku XX w. Zdziarski wskazał twórców, których dorobek był inspirowany folklorem i właśnie $z$ tego powodu cieszył się zainteresowaniem: „W literaturze [...] dramatycznej dwaj z najmłodszych - Rydel i Orkan - ulegli wpływowi ludowości"25. Ówcześni polscy pisarze widzieli w Orkanie ogromny potencjał, na przykład Przerwa-Tetmajer uważał, że właśnie tacy pisarze są w stanie stworzyć odrębną szkołę, podobną do ukraińskiej szkoły polskiego romantyzmu:

Górale mają swoją starą rodzimą tradycję, ale dopiero teraz poczynają się stykać z kulturą [...]. Jest bardzo prawdopodobnym, że wyjdą stamtąd na wskroś orygi-

\footnotetext{
21 І. Франко, Із чужих літератур (Сучасні польські поети), „Літературно-науковий вістник” 1899, t. 5 , ks. 3, s. 187-188. Tekst oryginału: „Син селянина 3 пруських Куяв, вихованець німецьких шкіл, він приніс зі собою дві речі, котрих не мала більшина польських поетів: докладне знання сільського життя і широку літературну освіту та очитання в класичних і новочасних літературах".

22 [I. Franko], Poezja Jana Kasprowicza, „Kurier Lwowski” 1889, nr 23, s. 6.

23 [I. Franko], Poezja Jana Kasprowicza, „Kurier Lwowski” 1889, nr 22, s. 1-2.

24 I. Franko, $Z$ dziedziny nauki i literatury, ,Kurier Lwowski” 1891, nr 242, s. 2.

25 S. Zdziarski, Władysław Orkan, [w:] Idem, Pierwiastek ludowy ..., op. cit., s. 570.
} 
nalni pisarze, muzycy, rzeźbiarze i malarze i że stworzą sobie w sztuce miejsce tak odrębne, jak ich ziemia odrębną jest od reszty kraju ${ }^{26}$.

Tetmajer podkreślał przy tym, że polska szkoła taką ,„...] miałaby wyższość nad ukraińską, że nie ograniczałaby się wyłącznie do literatury”27. Elementy folklorystyczne obecne były także w najnowszej literaturze ukraińskiej, dlatego Polacy chętnie przybliżali ją swoim czytelnikom ${ }^{28}$.

\section{LWOWSKIE POLEMIKI WOKÓŁ TWÓRCZOŚCI CZŁONKÓW „MŁODEJ MUZY”}

W ówczesnych wypowiedziach na temat wspólnych polsko-ukraińskich fascynacji folklorem podnoszone były też kwestie dotyczące odchodzenia młodych ukraińskich twórców od folklorystycznych źródeł twórczości, co zresztą obserwowali również niektórzy polscy krytycy. Na przykład Feliks Gwiżdż ${ }^{29}$ w 1907 r. opublikował na łamach warszawskiej „Prawdy” artykuł pt. Z literatury ruskiej, w którym opisał lwowskie środowisko ukraińskich pisarzy jako tych, którzy niepotrzebnie „oddalili się” od własnej kultury i jej ludowości. Autor zarzucał poetom ukraińskim, należącym do stowarzyszenia „Młoda Muza” ${ }^{30}$, odejście od „własnych źródeł”, a także naśladowanie literatury polskiej. Uważał, że młoda bohema ukraińska powinna naśladować Stefanyka - nowelistę-ekspresjonistę, który w niezwykły sposób potrafił opisać wszystkie zakamarki duszy ukraińskiego chłopa:

\footnotetext{
26 W. Orkan, Nowele (z przedmową K. Tetmajera), Warszawa 1898, s. 2.

27 Ibidem, s. 2.
}

28 A. Choroszy podkreśla, że jednym z najbardziej rozpoznawalnych oraz najczęściej thumaczonych pisarzy tamtego czasu był Wasyl Stefanyk. Ludowość ukraińskiego nowelisty doskonale współgrała z młodopolską estetyką. Patrz więcej [w:] A. Choroszy, Huculszczyzna w literaturze polskiej, Wrocław 1991, s. 348.

29 Feliks Gwiżdż „[...] uczęszczał na Uniwersytet Lwowski. Pierwsze utwory literackie (poezje, proza, recenzje) ogłaszał we lwowskim «Tygodniku» B. Wysłoucha (od r. 1903) [...]". J. Reychman, Gwiżḋ̇ Feliks, [w:] Polski stownik biograficzny, t. 9, Wrocław 1960-1961, s. 206.

30 Ukraińska „Młoda Muza” w historii ukraińskiego życia literackiego we Lwowie była stowarzyszeniem oryginalnym, gdyż jej członkowie realizowali idee włączenia twórczości ukraińskiej w nurt przemian kultury zachodniej, bez żadnych ograniczeń manifestowali własne poczucie przynależności do świata literatury zachodnioeuropejskiej. Do „Młodej Muzy” należeli: Bohdan Łepki, Wasyl Paczowski, Petro Karmanski, Ostap Łucki, Mychajło Jackiw, Sydir Twerdochlib i in. Patrz [w:] ,„Чрна Індія” „Молодої Музи”. Антологія прози і есеїстики, Львів 2014; A. Korniejenko, Ukraiński modernizm: próba periodyzacji procesu historycznoliterackiego, Kraków 1998; Т. Гундорова, ПроЯвлення Слова. Дискусія раннього украӥнського модернізму, Київ 2009; А. Matusiak, W kręgu secesji ukraińskiej. Wybrane problemy poetyki twórczości pisarzy „Młodej Muzy”, Wrocław 2006. 
Jest we Lwowie grupa poetów i literatów ruskich, która przypomina dzieci wiejskie, wyrzucone ze wsi na bruk miejski i tu błąkające się bez przytułku i oparcia żadnego ${ }^{31}$.

Dalej autor pisał:

Ten stan wyraża Mychajło Jackiw, jeden z przodujących nowelistów ukraińskich. Ale też nie więcej. On, Paczowski, Karmanski, Łucki kilku jeszcze innych, skupionych koło siebie, zbyt lekkomyślnie zapatrzyli się w nasze strony i gubiąc chodniki własne, wiodące od wsi, od chat ruskich, wkraczają na gościńce, na których łatwo zatracić wszystką świeżość wsi, a jeszcze łatwiej nasiąknąć dymem banalnym, tak smętnie włóczącym się po stronicach naszych rówieśnych tomików ${ }^{32}$.

Natomiast w następnym numerze „Prawdy” został zamieszczony tekst Karola Irzykowskiego, który całkowicie odciął się od recenzji Gwiżdża, ironicznie komentując wybrane jej fragmenty:

A gdzieżście wy: Jackow, Paczowski, Karmanski, Łucki? Dusza wasza siedzi gdzieś tam na jakichś stryszkach miejskich, a tu wieś was woła!

Biedny Jackowie, zachciało ci się być Jackowem, a nie Stefanykiem! Co za zarozumiałość! A przecież tak łatwo ci było iść za nim, masz wszystkie warunki po temu: znasz chłopa, połonina cię wypiastowała, znasz tysiące drobnych szczegółów chłopskich, sam jesteś chłopem (mogłeś do książki dodać swoją fotografię w chłopskim stroju!), dlaczegoż to wszystko marnujesz zamiast eksploatować, tym bardziej że przecież chłopskie rzeczy są dziś towarem modnym i popłatnym! $!^{33}$.

Jednak w innym artykule, Właża w swoje korzenie! Irzykowski wyraził pogląd, że ,„powrót do źródeł” nie ma na celu ograniczania twórczości artystycznej, a wręcz przeciwnie - może być impulsem do dalszego doskonalenia literatury.

Jakie znaczenie może mieć dla kultury w ogóle, a dla sztuki w szczególności zstępywanie do źródeł, przypominanie sobie różnych zaczątków [...]. Wracanie do źródeł może mieć tylko ten jedyny sens, że te źródła służą za przykłady, mające pośrednio oddziaływać na ocknienie się jednostronnie zacietrzewionej twórczości ${ }^{34}$.

31 F. Gwiżdż, Z literatury ruskiej, „Prawda: tygodnik polityczny, społeczny i literacki” 1907, nr 47 (1402), s. 557.

32 Ibidem, s. 558.

33 K. Irzykowski, Właża w swoje korzenie!, „Prawda: tygodnik polityczny, społeczny i literacki” 1907, nr 50 (1405), s. 592.

34 Ibidem, nr 51 (1406), s. 603-604. 
Irzykowski uważał też, że sięganie przez pisarzy do folkloru nie może być formą ucieczki przed problemami kultury początków XX w.: ,[...] współczesna polska świadomość, stanąwszy przed jakąś stromą ścianą, nie wie sama, co zrobić z sobą, i z tchórzostwa, czy z bezradności, włazi w swoje korzenie a dla odmiany także i w cudze" ${ }^{35}$ - twierdził.

Przy okazji prezentowania stanowiska Irzykowskiego należy wspomnieć, że większość polskich autorów i krytyków utożsamiała ówczesną literaturę ukraińską z kulturą ludową, dlatego też jej odchodzenie od źródeł folklorystycznych wywoływało sprzeciw. Właśnie w taki sposób dorobek literacki młodych twórców ukraińskich, którzy podążali za zachodnioeuropejskim nurtem estetycznym, oceniał Stanisław Zdziarski. Zamieścił on we lwowskim piśmie „Ruś” kontrowersyjny artykuł dotyczący ówczesnego stanu literatury ukraińskiej, w którym zdeprecjonował twórczość aktywnie działającego młodego pokolenia ukraińskich twórców: ,[...] Małorusini, przewyższający naród polski ilościowo dwukrotnie, nie mogą pochlubić się nazwiskami tej miary bodajby, co nasz Orkan, Józef Jedlicz lub znany poeta-chłop Ferdynand Kuraś" ${ }^{36}$. W artykule pt. Lirnicy poczajowsko-zarwaniccy odwoływał się do świeżo wydanej Antologii wspótczesnych poetów ukraińskich, do której wstęp napisał Władysław Orkan. Zdziarski zarzucał autorowi Komorników nieobiektywną ocenę poezji ukraińskiej wskazując, że jako poeta, a nie krytyk literacki, nie ma on odpowiednich kompetencji do jej oceny:

Pesymizmu [...] nie uważalibyśmy zresztą za grzech śmiertelny, gdyby poezja najmłodsza ruska była bodaj część tego warta, co o niej mniema p. Orkan. I w tym, że p. Orkan w mniemaniu swoim myli się, nie byłoby nic nienaturalnego: wiadomo, że poeci bywają przeważnie najgorszymi krytykami! Kiedy jednakowoż rzucono tutaj na społeczeństwo polskie gromy Jowiszowe za zupełną ignorancję w sprawach parnasowych małoruskich, godzi się postawić dwa skromne pytania: 1) czy zarzut ten zgodny jest z prawdą oraz 2) czy i o ile jest słuszny i uzasadniony? ${ }^{37}$.

Dalej, zarzucając Orkanowi niekompetencje przy opracowywaniu antologii, w sposób bardzo wyraźny deprecjonował sam dorobek ukraińskiej literatury:

[...] czyliż za szkodę uważać należy fakt, że społeczeństwo polskie nie zna współczesnej poezji małoruskiej, skoro na 95 utworów, napisanych przez 21 poetów (!!!), jakich przekłady znajdziemy w Antologii, - co najwyżej część piąta da się jako tako, od biedy raczej, podciągnąć pod miano „poezji” ${ }^{38}$.

$35 \quad$ Ibidem, nr 50 (1405), s. 592.

36 S. Zdziarski, Lirnicy poczajowsko-zarwaniccy, „Ruś. Czasopismo poświęcone dziejom i kulturze Ukrainy, Podola, Wołynia i Rusi Czerwonej” 1911, z. 3, s. 327.

37 Ibidem, s. 318.

$38 \quad$ Ibidem, s. 319. 
Istotne staje się pytanie o to, co mogło spowodować napisanie tekstu tak mocno obniżającego wartość ówczesnej literatury ukraińskiej przez autora interesujących recenzji prac Szuchewycza Huculszczyzna ${ }^{39}$ lub Kolessy Ukraińska rytmika ludowa $w$ poezyach Bohdana Zaleskiego ${ }^{40}$. Odpowiedzi na to pytanie próbował częściowo udzielić Mychajło Jackiw, który we lwowskim „Życiu” opublikował artykuł pt. Fatszerz krytyki, zarzucając Zdziarskiemu brak etyki i kompetencji krytyczno-literackich: „Mam lat czterdzieści; widziałem wiele w swym życiu i czytałem wiele, lecz wyznaję otwarcie: podobnego przejawu zgnilizny moralnej w poważnej krytyce i w nauce nie spotykałem nigdy"41. Ukraiński pisarz potępiał postawę Zdziarskiego, który skupił się na ,pokazaniu polskim czytelnikom, jakimi to prymitywami operuje jeszcze ukraińska poezja" ${ }^{42}$. Zdaniem Jackowa polski krytyk nie kierował się obiektywizmem, lecz pisał tendencyjne teksty, dopasowane do profilu ideologicznego poszczególnych pism:

Od dłuższego czasu szerszy ogół polski interesuje się poezją i literaturą ukraińską. Od krytyków, którzy zadali sobie niemało trudu nad pogłębieniem istoty nowych twórczych objawów na niwie ukraińskiej, odbiegł specjalnie p. dr. Stanisław Zdziarski i zabrawszy kazuistycznym zbiegiem przypadku ten dział w arendę, sypie jak z rogu obfitości recenzję za recenzją, gdzie go nie posiejesz - wczoraj w „Słowie Polskim”, w końcu w lwowskim kwartalniku „Ruś” itd. A mnoży p. Z. całą moc swych krytyk i studiów na temat Młodej Ukrainy i zależy mu na pośpiechu tak dalece, że z artykułu w „Rusi” odczuwa się stęchliznę zatłuszczonej książeczki do modlenia, co pozwala przypuszczać, że artykuł ten był przeznaczony do „Przeglądu Powszechnego”, zaś artykuł zamieszczony w „Świecie Słowiańskim”, był pisany dla „Rusi”, lecz wycofano go stamtąd przed czasem, czy dla braku pieniędzy, czy z innych powodów, i w ostatniej chwili nie zdołano nawet przewietrzyć i wytrzepać należycie ${ }^{43}$.

W twórczości poetyckiej Petra Karmanskiego Zdziarski dostrzegał naśladownictwo liryki Kazimierza Przerwy-Tetmajera, podobieństwo to charakteryzując przy tym jako rozpaczliwe oraz smutne bezgranicznie ${ }^{44}$ :

Był on już wcale skrajnym pesymistą jeszcze wówczas, gdy w zbiorku pt. $O j$, luli smutku! wołał z każdej strony niemal „Vorei morir”! Po upływie zaś bardzo

\footnotetext{
39 W. Szuchiewicz, Huculszczyzna (Stanisław Zdziarski), „Lud. Organ Towarzystwa Ludoznawczego we Lwowie" 1903, r. 9, s. 415-416.

40 A. Kolessa, Ukraińska rytmika ludowa w poezjach Bohdana Zaleskiego (St. Zdziarski), „Lud. Organ Towarzystwa Ludoznawczego we Lwowie” 1901, r. 7, s. 227.

${ }_{41}$ M. Jackiw, Fatszerz krytyki, „Życie” 1911, z. 6, s. 91.

42 Ibidem, s. 90.

43 Ibidem, s. 89.

44 S. Zdziarski, Lirnicy poczajowsko-zarwaniccy, „Ruś. Czasopismo poświęcone dziejom i kulturze Ukrainy, Podola, Wołynia i Rusi Czerwonej” 1911, z. 3, s. 319.
} 
krótkiego czasu doszedł do skrajnej negacji bytu, kiedy zdolny jest do apoteozy śmierci, kiedy w zachwycie, z lubością przedziwną tęskni i jakby na przekór czy przedrzeźniając się Tetmajerowi woła: „Evviva l'morte”!... ${ }^{45}$.

Jednak wiersze niektórych młodomuzowców, między innymi twórczość Sydora Twerdochliba, oceniał pozytywnie:

Talentu dużo, zrównoważenia również, pozy brak. A czyliż to mało jeszcze? Zarówno wiersze nastrojowe, jak opisowe odznaczają się subtelnością ujęcia i zacięciem muzycznym do tego stopnia, że niektóre utwory jego czynią wrażenie, jak gdyby były pisane umyślnie pod muzykę $[\ldots]^{46}$.

Omawiając z kolei poezję Wasyla Paczowskiego uważał, że: „Duszy poety nie tknął jeszcze robak zepsucia" ${ }^{47}$.

Można przypuszczać, że przyczyną tak kontrowersyjnych ocen twórczości młodych ukraińskich literatów było myślenie Zdziarskiego, że nadmierne inspirowanie się kulturą zachodnioeuropejską prowadzi do utraty własnej oryginalności. Zdziarski bowiem deprecjonował nurty kultury europejskiego Zachodu - jak stwierdzał Jackiw - nie rozumiejąc ich istoty.

Zdziarski ,[...] przechodzi do pesymizmu w literaturze europejskiej i ni stąd, ni zowąd, nie mając pojęcia o jej podłożu duchowym, imputuje go poezji ukraińskiej [...]. Dalej rozumie się, że p. Orkan musi się zaraz we wstępie do wymienionej książki „mylić”, bo jakżeby inaczej kontrast między nim jako poetą a p. dr. Zdziarskim jako „krytykiem” wyglądał!?48.

Z perspektywy XXI wieku wypowiedź Zdziarskiego można interpretować jako znak pogorszania się polsko-ukraińskich relacji we Lwowie ze względu na konteksty narodowościowe. Jednak ani autor artykułu Lirnicy poczajowsko-zarwaniccy, ani Jackiw w swoich rozważaniach nie artykułowali tego zagadnienia wprost, a przedmiotem ich dyskusji pozostawała literatura. Na uwagę zasługuje jeszcze jedna kwestia, którą uwypuklał Jackiw jako członek „Młodej Muzy”. Zdziarski pisząc o France, pomijał kilka bardzo ważnych utworów tego autora, a skupiał się na poemacie Mojżesz, z którego na siłę wydobywał strofę wpisującą się w mocno tendencyjny tok wypowiedzi interpretacyjnej. Co więcej, Zdziarski nie brał w swoich rozważaniach pod uwagę innych zdolnych poetów ukraińskich i skupiał się wyłącznie na twórczości pisarzy poszukujących własnego stylu.

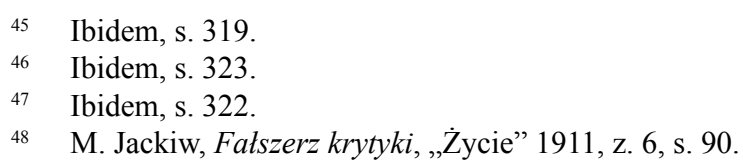




\section{POLACY I UKRAIŃCY O HUCULSZCZYŹNIE WOŁODYMYRA SZUCHEWYCZA}

Pisząc o fascynacji kulturą ludową na przełomie XIX i XX wieku, nie sposób ominąć Wołodymyra Szuchewycza (w wydaniach polskich bardziej znanego jako Włodzimierz Szuchiewicz), ukraińskiego etnografa, którego głównym obszarem zainteresowań było życie górali wschodniokarpackich, i nie sposób nie przypomnieć okoliczności wydania jego Huculszczyzny. Szuchewycz, przygotowując pracę etnograficzną, udostępnił polskim i ukraińskim środowiskom literackim, zafascynowanym kulturą ludową, obszerny zasób wiedzy o życiu mieszkańców Karpat Wschodnich.

Publikacja ukazała się w 1899 roku nakładem działu etnograficznego Muzeum imienia Dzieduszyckich we Lwowie dzięki hr. Włodzimierzowi Dzieduszyckiemu. Praca rozrosła się do rozmiarów czterotomowego dzieła (nie licząc pierwszego tomu napisanego w języku ukraińskim). Dwa tomy zostały opublikowane w roku 1902, trzeci w 1904, natomiast ostatni cztery lata później, w roku 1908 . We wstępie do czwartego tomu autor odsłonił kulisy wydania obszernej pracy. Oddając w nim ,głęboką cześć pamięci nieodżałowanego założyciela Muzeum im. Dzieduszyckich, śp. Ekscelencji Włodzimierza hr. Dzieduszyckiego" ${ }^{49}$, informował jednocześnie: ,poznawszy treść I-go tomu Huculszczyzny, wydanego w języku rusińskim, [hr. Dzieduszycki] testamentem zabezpieczył osobny fundusz na wydanie mej pracy o Huculszczyźnie w języku polskim [...]" ${ }^{\prime 50}$. Z przedmowy dowiadujemy się również o szczegółach, dzięki którym możliwa była kontynuacja pierwszego tomu Huculszczyzny:

[Tadeusz hr. Dzieduszycki,] spełniając ostatnią wolę swego wielkiego poprzednika, pokrywał ze wszelką gotowością wszystkie koszty wydawnictwa i łącznie z Naukowym Towarzystwem im. Szewczenki, które wydało pierwsze części niniejszej pracy w języku rusińskim, podniósł wartość wydawnictwa wielkim bogactwem rycin $[\ldots]^{51}$.

Szuchewycz współpracował z Muzeum im. Dzieduszyckich nie tylko w okresie pisania swego dzieła, swoją wiedzą służył również przy powstaniu działu etnograficznego Muzeum ${ }^{52}$. Gabriel Brzęk podkreśla też inną ważną

49 W. Szuchiewicz, Przedmowa, [w:] Idem, Huculszczyzna, t. IV, Lwów 1908, [s. 2].

50 Ibidem.

51 Ibidem.

52 Zob.: [b.a.], Wystawa krajowa, „Dodatek do nr 182 Kuriera Lwowskiego” 1894, s. 1. $\mathrm{O}$ współpracy Szuchewycza z hr. Dzieduszyckim podczas powstania działu etnograficznego Muzeum wspomina w nekrologu pt. Володимир Шухевич Jewhen Olesnycki: „W pracy tej znalazł [Szuchewycz] wsparcie u śp. hr. W. Dzieduszyckiego, z którym współpracował przy planowaniu działu etnograficznego w muzeum przyrodniczym im. Dzieduszyckich we Lwowie”. (Е. Олесницький, Володимир Шухевич, „Збруч”, [źródło internetowe:] https://zbruc. 
rzecz - wszyscy doradcy poszczególnych działów Muzeum „byli przedtem okresowo stypendystami Dzieduszyckiego" ${ }^{53}$. Działalność hrabiego w zakresie nauki i kultury została doceniana przez Ukraińców, wśród których Dzieduszycki cieszył się ogromnym szacunkiem. Świadczył o tym chociażby nekrolog opublikowany na łamach „Literaturno-Naukowego Wistnyka”: „Hr. Włodzimierz Dzieduszycki, założyciel pięknego muzeum we Lwowie, szczery zwolennik studiów nad życiem i przemysłem naszego narodu, człowiek szlachetny, przejęty idealnymi zmaganiami zmarł pod koniec września br. w swojej siedzibie Poturzycy" 54 .

Dla młodopolskiego i młodoukraińskiego życia literackiego we Lwowie publikacja o Huculszczyźnie była niezwykle atrakcyjna. Fascynacja folklorem, charakteryzująca polskich i ukraińskich artystów, motywowała do napisania pracy o ludności zamieszkującej tereny Karpat Wschodnich, dlatego Praca Szuchewycza cieszyła się ogromnym zainteresowaniem, czego dowodem były jej omówienia na łamach „Literaturno-Naukowego Wistnyka”, „Ludu” oraz „Tygodnia” (dodatku „Kuriera Lwowskiego”). Warto przy tym podkreślić, że Szuchewycz, podobnie jak Franko czy Łepki, płynnie władał językiem polskim, dlatego Huculszczyzna nie musiała być tłumaczona z języka ukraińskiego. „Literaturno-Naukowyj Wistnyk” zamieścił informację:

Nasi Huculi, chociaż stanowią bardzo interesujący typ zarówno dla etnografa, jak i antropologa, dotychczas prawie nie byli opisywani od strony naukowej. [...] Szczególnie dużo w tym kierunku zrobił dr W. Szuchewycz, który właśnie pracuje nad szerszą pracą o Hucułach dla wydawnictw Naukowego Towarzystwa im. Szewczenki. Jego działalność wzbogaciła również Muzeum Dzieduszyckich we Lwowie $[\ldots]^{55}$.

Zdziarski w artykule zamieszczonym w czasopiśmie „Lud” podkreślał znaczenie pracy Szuchewycza dla badaczy nie tylko zgłębiających obycza-

eu/node/35433 [dostęp: 6.12.2018]. Publikacja na stronie czasopisma „Збруч” jest przedrukiem z czasopima „Diło” 1915, 24.04.1915.

53 G. Brzęk, Muzeum im. Dzieduszyckich we Lwowie i jego Twórca, Lublin 1994, s. 146.

54 [b. а.], Персоналія, „Літературно-науковий вістник” 1899, t. 8, ks. 10, s. 47. Tekst oryginału: „Гр. Володимир Дідушицкий, основатель прекрасного музея у Львові, щирий прихильник студій над життям і промислом нашого народу, чоловік високо-благородний, простий і пронятий ідеальними змаганнями, помер при кінці вересня с. р. в своїм маєтку Потуриці".

55 [b. а.], Хроніка і бібліографія (II.) Нові книжки, „Літературно-науковий вістник” 1899, t. 7 , ks. 8, s. 121-122. Tekst oryginału: „Наші Гуцули, хоч виявляють, незвичайно цікавий тип так для етнографа, як і для антрополога, дотепер майже зовсім не досліджені 3 наукового боку. Ледви в останніх часах замітна зміна до ліпшого. Особливо багато зробив у тім напрямі д. В. Шухевич, що тепер власне виготовлює ширшу працю про Гуцулів для видань наук. Товариства ім. Шевченка". Його заходами збагатився також Музей Дідушицьких у Львові [...]”. 
jową stronę życia mieszkańców Karpat wschodnich, lecz również stykających się z kulturą zakopiańską, mającą wiele wspólnego z kulturą góralską wschodnich sąsiadów:

Pomimo dość licznych stosunkowo u nas prac o Hucułach, nie mieliśmy dotąd, nie powiem już wyczerpujących, o tym górskim ludzie wiadomości, ale nawet nie wiedzieliśmy o nim niczego dokładnie. Znajomość rzeczy huculskich, tak bardzo potrzebną każdemu badaczowi Zakopiańszczyzny i Podhala w ogóle, gdyż mają one wiele wspólnego z życiem naszych górali, ułatwił znakomicie p. Szuchiewicz pracą omawianąa ${ }^{56}$.

W gazecie „Tydzień” ukazała się natomiast recenzja Ernesta Łunińskiego, który etnograficzną pracę przedstawiał następująco: „Gazdy wschodniego Beskidu doczekali się wspaniałej, wyczerpującej monografii. Prof. Włodzimierz Szuchiewicz przysłużył się bardzo swemu społeczeństwu, przysłużył się i nam, wydając swą pracę nie tylko w języku ruskim, ale i polskim" ${ }^{57}$. Łuniński wysoko oceniał Huculszczyznę, gdyż - jak twierdził - utrwalono w niej

[...] wszytko, co się utrwalić dało, $\mathrm{z}$ dziwnym pietyzmem i z jeszcze dziwniejszą benedyktyńską pracą. Gdyby dziś huculszczyzna przepadła, byłoby to dzieło magna parens spiritualis... na jej gruzach... Z niego ona wygląda cała taką, jaką jest, w objawach swoich etnograficznych, fizjograficznych, architektonicznych, zwyczajowych ${ }^{58}$.

Co ciekawe, wspomniana recenzja składała się z dwóch części. Drugą z nich napisał architekt Kazimierz Mokłowski, który starał się uświadomić polskiemu czytelnikowi, jak dużo wspólnego ze sobą mają polscy i rusińscy górale.

Górale polscy i ruscy zamieszkają bowiem jedno i to samo pasmo gór, etnicznie są sobie spokrewnieni, żyją wśród prawie zupełnie podobnych warunków przyrodniczych i gospodarczych, tak że lepiej jest dla nauki porównać sztukę Podhala ze sztuką huculską, zamiast udawać się [...] do odległej Polinezji [...] dla wyszukania poczciwym polskim góralom krewniaków w artyzmie ${ }^{59}$.

\footnotetext{
56 W. Szuchiewicz, Huculszczyzna (Stanisław Zdziarski), „Lud. Organ Towarzystwa Ludoznawczego we Lwowie" 1903, r. 9, s. 415.

57 E. Łuniński, Huculszczyzna, „Tydzień” (dodatek „Kuriera Lwowskiego”) 1902, nr 45, s. 707.

58 Ibidem, s. 708-709.

59 K. Mokłowski, Huculszczyzna, „Tydzień” (dodatek „Kuriera Lwowskiego”) 1902, nr 48, s. 765 .
} 
Mokłowskiemu udało się odnaleźć cechy wspólne dla ludu podhalańskiego i Hucułów, a tym samym podkreślić, jak bardzo kultura polska i ukraińska wzbogaciły się dzięki tym grupom etnicznym: ,,...] Podhale nosi na sobie znak dziejów kultury tysiącletniej całego narodu polskiego, czyni ze sztuki górali polskich sztukę polską, tak jak zdobniczość Hucułów jest bukowińsko-ruską" ${ }^{60}$.

Nie ulega wątpliwości, że Huculszczyzna musiała być szczegółowo omawiana $\mathrm{w}$ ukraińskim środowisku naukowym, gdyż wysoka ocena tej pracy przez polskich intelektualistów wymagała jej weryfikacji w ukraińskich kręgach intelektualnych. Ukazanie się Huculszczyzny w języku polskim z ukraińskiego punktu widzenia było bardzo korzystne, ponieważ służyło popularyzacji dorobku naukowego wśród Polaków. Jednak w roku 1905 doszło do polemiki, którą można potraktować jako ciekawostkę, a zainicjował ją sam Szuchewycz. Jej upamiętnienie znajduje się w sprawozdaniach z posiedzeń NTSz. Spór dotyczył objętości Huculszczyzny w języku polskim i ukraińskim. Z niewiadomych powodów autor pracy przekonywał uczestników posiedzenia, że ukraińska wersja publikacji w żadnym wypadku nie jest mniejsza od wersji polskiej:

Na posiedzeniu NTSz we Lwowie w dniu 19 kwietnia 1905 r. dr W. Szuchewycz w trakcie dyskusji nt. Huculszczyny oznajmił i powtórzył swoje słowa parę razy w obecności 52 członków, że jeśli ktoś wykaże mu, że polskie wydanie Huculszczyny ma o dwie strony więcej tekstu niż wydanie rusińskie, to złoży 500 koron na cel publiczny. Niżej podpisany [dr Buraczyńskyj], porównując oba wydania, stwierdził, że w wydaniu polskim jest: 1) O jedną mapkę więcej; 2) O jedną kliszę więcej; 3) 13 (trzynaście) stron +18 wersów tekstu, czego nie ma w rusińskim wydaniu. O tym zresztą wiedział dr W. Szuchewycz [...], ponieważ w przedmowie do Huculszczyzny (t. I, 1902, s. VIII) napisał: „Uzupełnienie braków i uporządkowanie materiału działu przemysłu domowego spowodowało pewną zwłokę niniejszego wydania, jednakowoż nie bez korzyści dla całości, gdyż przy tej sposobności udało się mi uzupełnić i inne działy niniejszej pracy, skutkiem czego wydanie polskie pierwszego tomu jest obszerniejsze niż ruskie, które wyszło przed ostateczną decyzją co do wydania „Huculszczyzny” w języku polskim”. Wobec tego niżej podpisany prosi dra Szuchewycza o wyciągnięcie ze swojego oświadczenia odpowiednich konsekwencji ${ }^{61}$.

\footnotetext{
60 Ibidem, s. 765.

${ }_{61}$ Е. Бурачинський, 3 поза редакції. Заява, “Літературно-науковий вістник” 1905, t. 31, ks. 7, s. 104. Tekst oryginału: На загальних зборах Наук. Тов. ім. Шевченка у Львові дня 19 цьвітня 1905 р. заявив д. Вол. Шухевич у дискусії над “Гуцульщиною” і повторив свої слова пару разів у присутности 52 членів, що хто викаже йому, буцім то польське виданє "Гуцульщини" більше текстом від руського хоч на дві сторінки, він зложить 500 корон на публічну ціль. Підписаний [д-р Бурачинський], порівнявши оба видання 3 собою, сконстатував, що в польськім виданню є: 1) Одна мапка більше; 2) Один кліш більше; 3) 13 (тринадцять) стор. +18 стрічок тексту, якого нема в руськім виданню. Про се знав зрештою д. В. Шухевич [...], бо в передмові до "Нuculszczyzny" (т. I, 1902 р. ст. VIII) написав: „Uzupełnienie braków i uporządkowanie materiału działu przemysłu domowego spo-
} 
W tymże roku w jednym z numerów "Literatuno-naukowego Wistnyka" ukazał się artykuł Franki, naświetlający inne okoliczności, pogłębiające polemikę Szuchewycza z NTSz. Niezależnie od wysokiej oceny Huculszczyzny, autor tekstu opisuje wydarzenia, które towarzyszyły powstaniu pracy, m.in. udostępnienie przez NTSz klisz, wzbogacających stronę wizualną publikacji. Jak zaznacza, Franko, między Szuchewyczem a NTSz powstała „gęsta siatka nieporozumień" ${ }^{\prime 2}$, dotycząca wykorzystania materiałów ilustracyjnych, zamieszczonych w Huculszczyźnie (większość klisz była własnością NTSz, chociaż Szuchewycz wymienia w pracy tylko Muzeum im. Dzieduszyckich). Poszczególne części Huculszczyny zostały także poddane przez Frankę analizie merytorycznej i językowej, czego efektem były jego publikacje w niemieckojęzcznym piśmie „Zeitschrift für oesterreichische Volkskunde” oraz Wołodymyra Hnatiuka w gazecie „Kiewskaja Starina” ${ }^{63}$. Na recenzję Hnatiuka Szuchewycz zareagował gwałtownie, dlatego postanowił na nią odpowiedzieć obszernym artykułem w tymże czasopiśmie, a także opublikować ten tekst jako dodatek do lwowskiej gazety "Diło" 1905 (cz. 125).

Według Franki, reakcja Szuchewycza na krytykę Hnatiuka była zbyt emocjonalna i nierozsądna. Autor Huculszczyzny powinien docenić skrupulatną analizę jego dokonania chociażby ze względu na fakt, iż jej autorem był znany ukraiński naukowiec oraz członek NTSz. Z informacji, które udostępnił czytelnikom Franko, wynika także, że w żadnym tomie Huculszyzny nie zostały wymienione nazwiska osób, które przyczyniły się do powstania tej publikacji: ,$[\ldots]$ dr Szuchewycz nie wspomniał ludzi, którzy dostarczali mu materiały dla jego pracy, [...] prof. Szuch. dopiero teraz obiecuje wymienić ich nazwiska w przedmowie do zapowiedzianego piątego tomu [...]"64. Spór ten najwyraźniej pokazuje, że w ukraińskim środowisku intelektualnym krytykę trakto-

wodowało pewną zwłokę niniejszego wydania, jednakowoż nie bez korzyści dla całości, gdyż przy tej sposobności udało się mi uzupełnić i inne działy niniejszej pracy, skutkiem czego wydanie polskie pierwszego tomu jest obszerniejsze niż ruskie, które wyszło przed ostateczną decyzją co do wydania „Huculszczyzny” w języku polskim”.Супроти того просить підписаний д. В. Шухевича витягнути зі своєї заяви відповідні консеквенції.

62 І. Франко, Дещзо про нашу пресу..., ор. cit., s. 179.

63 М. Р. [В. Гнатюк], Гуиульщина. Написав проф. Володимир Шухевич. У Львові. Накладом Наукового Товариства ім. Шевченка. Bип. I, 1899; вип. III, 1901; вип. III, 1902; вип. IV, 1904, „Кіевская старина” 1905, nr 88, s. 73-122. Główne zarzuty Hnatiuka szczegółowo omawia A. Karpenko w artykule pt. Паспортизачія польових етнографічних матеріалів 3 „Гуиульщини” як основа визначення територіального засягу прачі Володимира Шухевича, s. 216-217, [w:] „Вісник Львівського університету. Серія історична" 2016, вип. 52.

64 I. Франко, Дещо про нашу пресу..., ор. cit., s. 176. Tekst oryginału: „[...] д. Шухевич не згадав про людей, які достарчали йому матеріялів для його праці, [...] проф. Шух. тілько тепер обіцює згадати їх у передмові до заповідженого пятого тому [...]”. 
wano nie jako okazję do udoskonalenia własnej pracy, lecz jako zagrożenie i deprecjację wartości naukowego dorobku.

Reasumując, prace Szuchewycza, które zostały opublikowane w języku polskim, bez wątpienia przyczyniły się do wzmocnienia relacji pomiędzy polskimi i ukraińskimi intelektualistami, świadcząc również o tym, że doskonała znajomość języka polskiego przez niektórych ukraińskich naukowców i pisarzy znacznie ułatwiała proces zbliżenia intelektualnego i kulturowego dwóch narodów. Warto również podkreślić, że polskojęzyczne wydania ukraińskich prac wywoływały dyskusje w polskich i ukraińskich środowiskach intelektualnych. Stanisław Zdziarski wysoko oceniał Huculszczyne przede wszystkim dlatego, że tematyka tej pracy doskonale wpisywała się w krąg jego zainteresowań naukowych. Co więcej, praca dostarczyła wielu informacji etnograficznych ówczesnym polskim uczonym, z których nie każdy władał językiem ukraińskim.

\section{ZAKOŃCZENIE}

Kultura ludowa stała się elementem scalającym polskie i ukraińskie środowiska intelektualne we Lwowie. Dyskusje i spory, których tematem przewodnim była ludowość, pokazują dynamikę rozwoju tych relacji, natomiast teksty, ukazujące się na łamach wybranych pism, odzwierciedlają specyfikę kontaktów Polaków i Ukraińców na polu naukowym. Zarówno polscy, jak i ukraińscy pisarze doceniali wartość obecnych w literaturze motywów i wątków ludowych jako wnoszących świeżość i zapewniających oryginalność ówczesnej twórczości literackiej. Stąd rozważania na temat inspiracji kulturą ludową tworzyły oryginalną płaszczyznę rozwoju polsko-ukraińskiej krytyki literackiej we Lwowie na przełomie XIX i XX wieku.

Narastająca świadomość wartości polsko-ukraińskiej współpracy intelektualnej w przestrzeni folklorystycznej ujawniła się w międzywojennym Lwowie, czego świadectwem są wspomnienia Bohdana Łepkiego o Władysławie Orkanie i Wasylu Stefanyku ${ }^{65}$, Jana Kasprowicza o Iwanie France ${ }^{66}$ lub wypowiedź Stanisława Przybyszewskiego o Stefanyku z okazji 25-lecia twórczości ukraińskiego nowelisty ${ }^{67}$. Teksty te pokazują, w jaki sposób ludowość oddziaływała na utrwalanie kontaktów polskich i ukraińskich intelektualistów zarówno w przestrzeni artystycznej, jak i personalnej. W tym też czasie Adam Fischer - stypendysta, a później pracownik Zakładu Narodowego im. Osso-

\footnotetext{
65 Zob.: Б. Лепкий, Три портрети. Франко - Стефаник-Оркан, [s.n.], Львів 1937.

66 Zob.: Wiadomości ukraińskie. Wspomnienia Jana Kasprowicza o Iwanie France. - Rozwiązanie ,Siczy”. - Z żałobnej karty (Lwów 25 maja), „Chwila” 1926, nr 2580, s. 7.

67 Zob.: I. Кедрин, „Iз землі зродженому твориеві”... Спомини Станислава Пииибишевського про Василя Стефаника, „Діло” 1926, 26 грудня, s. 2.
} 
lińskich, etnolog i folklorysta - w pracy pt. Rusini wymienia nazwiska ukraińskich intelektualistów (Iwana Franki, Wołodymyra Hnatiuka, Oleksandra Kolessy, Wołodymyra Szuchewycza), których publikacje stanowią bogate źródło informacji o Rusinach ${ }^{68}$. Co więcej, Fischer podkreśla, że etnografia ruska

rozwinęła się [...] w znacznym stopniu dzięki współpracy uczonych polskich. Rzecz to zupełnie zrozumiała, gdyż Polskę z Rusią łączyły i łączą liczne związki kulturalne, które zaznaczyły się także w literaturze w tak zwanej szkole ukraińskiej. Byłoby bardzo pożądane, by to wzajemne współdziałanie trwało i nadał $[. . .]^{69}$.

\section{BIBLIOGRAFIA}

[Franko Iwan]. 1889. Poezja Jana Kasprowicza. „Kurier Lwowski” nr 23: 2-3.

Choroszy Jan Andrzej. 1991. Huculszczyna w literaturze polskiej. Wrocław: wyd. J. Choroszy.

Franko Iwan. 1885. Adam Mickiewicz w rusińskiej literaturze. „Kraj” nr 46: 28-29.

Gwiżdż Feliks. 1907. Z literatury ruskiej. „Prawda: tygodnik polityczny, społeczny i literacki” nr 47 (1402): 557-558.

Irzykowski Karol. 1907. Właża w swoje korzenie!. „Prawda: tygodnik polityczny, społeczny i literacki” nr 50 (1405): 592 oraz nr 51 (1406): 603-604.

Jackiw Mychajło. 1911. Fatszerz krytyki. „Życie” z. 6: 89-92.

Kolessa Aleksander. 1900. Ukraińska rytmika ludowa w poezyach Bohdana Zaleskiego. Lwów: nakł. Senatu Uniwersytetu Lwowskiego.

Pavličko Solomiâ. 1997. Diskurs modernizmu v ukraïns'kij literaturì. Kiïv: „Libìd”. [Павличко Соломія. 1997. Дискурс модернізму в украӥнській літературі. Київ: "Либідь"].

Szuchiewicz Włodzimierz. 1908. Huculszczyzna. T. IV. Lwów: nakładem Muzeum imienia Dzieduszyckich.

Zdziarski Stanisław. 1904. Bohdan Zaleski. Studium biograficzno-literackie. Lwów: Towarzystwo Wydawnicze.

Zdziarski Stanisław. 1901. Pierwiastek ludowy w poezji polskiej XIX wieku. Studia porównawczo-literackie. Lwów: Drukarnia Ludowa we Lwowie.

Zdziarski Stanisław. 1911. Lirnicy poczajowsko-zarwaniccy. „Ruś. Czasopismo poświęcone dziejom i kulturze Ukrainy, Podola, Wołynia i Rusi Czerwonej” z. 3: 318-327.

\section{KULTURA LUDOWA JAKO WSPÓLNY PRZEDMIOT ZAINTERESOWAŃ POLSKICH I UKRAIŃSKICH TWÓRCÓW ORAZ BADACZY WE LWOWIE NA PRZEŁOMIE XIX I XX WIEKU}

Streszczenie. Szkic jest próbą zrekonstruowania polsko-ukraińskich dyskusji o literaturze we Lwowie, uwzględniających obecność kultury ludowej w twórczości. Ma charakter historyczno-przeglądowy, zastosowano w nim również metodę porównawczą. Fascynacja

68 Dzieje ruskiej etnografii, s. 171, [w:] A. Fischer, Rusini, Lwów 1928.

${ }_{69}$ Dzieje ruskiej etnografii, s. 172, [w:] A. Fischer, Rusini, Lwów 1928. 
ludowością z jednej strony jednoczyła polskich i ukraińskich intelektualistów, zaś z drugiej niejednokrotnie była powodem sporów wewnątrz tych środowisk. Teksty krytyczno-literackie o tematyce ludowej, ukazujące się na łamach wybranej prasy lwowskiej na przełomie XIX i XX wieku, są świadectwem aktywnej współpracy intelektualnej Polaków i Ukraińców, a także wzajemnego zainteresowania rozwojem kultury sąsiada.

Słowa klucze: dyskusje polsko-ukraińskie, literatura, kultura ludowa, Lwów, przełom XIX i XX wieku

\title{
НАРОДНА КУЛЬТУРА ЯК ЗАГАЛЬНИЙ ПРЕДМЕТ ІНТЕРЕСУ ПОЛЬСЬКИХ ТА УКРАЇНСЬКИХ МИТЦІВ ТА ДОСЛІДНИКІВ У ЛЬВОВІ НА ЗЛАМІ ХІХ-ХХ СТОЛІТЬ
}

\begin{abstract}
Анотація: Дана стаття є спробою реконструювати польсько-українські дискусії про літературу у Львові, з урахуванням присутності народної культури у творчості. Вона має історико-оглядовий характер, хоча тут автором використовувався порівняльний метод. 3 одного боку, захоплення народництвом об'єднувало польську та українську інтелігенцію, а з іншого - часто було причиною суперечок у цих колах. Критично-літературні тексти на народну тематику, опубліковані в добірній львівській пресі на зламі XIX-XX століть, є свідченням активної інтелектуальної співпраці поляків та українців, а також обопільної зацікавленості у розвитку культури сусідів.
\end{abstract}

Ключові слова: Польсько-українські дискусії, література, народна культура, Львів, злам XIX-XX століть 